UNDERGRADUATE RESEARCH IN NATURAL AND CLINICAL SCIENCE AND TECHNOLOGY (URNCST) JOURNAL Read more URNCST Journal articles and submit your own today at: https://www.urncst.com

CONFERENCE ABSTRACT BOOK

OPEN ACCESS

\title{
Scinapse 2017-2018 Undergraduate Science Case Competition: What the Frack is this?
}

Dilpreet Bajwa, BHSc Student [1], Iulia Cornila, BSc Student [1], Jamie Ghossein, BSc, MD Student [1]*, Rashida Rajgara, MSc, PhD Student [1]

[1] Faculty of Medicine, University of Ottawa, Ottawa, ON, Canada.

*Corresponding Author: j.ghossein@uottawa.ca

All authors contributed equally.

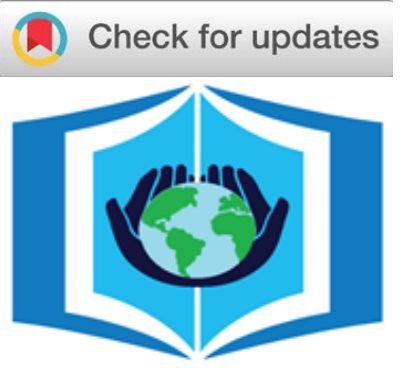

URNCST Journal

"Research in Earnest"

\begin{abstract}
The Scinapse Undergraduate Science Case Competition (USCC) allows undergraduate students to experience the development of a new research proposal based off a given topic. A case is presented to all participants and using an in-depth literature search (publications, reports, studies and published writings), students connect and pinpoint key elements allowing them to construct a hypothesis in support of the case in question. The participants will then design a controlled experiment to determine whether their hypothesis is valid or not. Students register in teams of 2-4. The first round of the USCC involves the submission of a written proposal. The top $10 \%$ of proposals will be invited to uOttawa to compete in a poster competition against finalists of other universities from across the province. This year's topic was hydraulic fracturing, a process that entails many environmental and health related challenges. The 2018 USCC attracted 743 students from 9 universities across the country, the top $25 \%$ of written submissions are highlighted in this abstract booklet. Scinapse is part of a larger organization, Undergraduate Research Initiative (URI), with the primary goal of inciting interest in research and developing related skills. More information on Scinapse and URI can be found at http://scinapsescience.com and http://uri-irpc.ca.
\end{abstract}

Keywords: hydraulic fracturing; fracking; undergraduate research; science case competition; global health; pollution

\section{Table of Contents}

Lower Division ( $1^{\text {st }}$ and $2^{\text {nd }}$ year students)

pg. A02-A12

Biomedical Sciences and Chemistry

Biology

Engineering

Geology, Physical and Earth Sciences

Global Health

Mathematics and Physics

Upper Division ( $3^{\text {rd }}$ year and above students)

Biomedical Sciences and Chemistry

Biology

Engineering

Geology, Physical and Earth Sciences

Global Health pg. A02-A06 pg. A06-A07 pg. A07-A08 pg. A08-A10 pg. A10-A11 pg. A11-A12 pg. A12-A19 pg. A12-A14 pg. A15-A16 pg. A16-A17 pg. A18-A18 pg. A18-A19

\section{Conference Abstracts}

Note: These abstracts have been reproduced directly from the material supplied by the authors, without editorial alteration by the staff of the URNCST Journal. Insufficiencies of preparation, grammar, spelling, style, syntax, and usage are the authors. 
UNDERGRADUATE RESEARCH IN NATURAL AND CLINICAL SCIENCE AND TECHNOLOGY (URNCST) JOURNAL Read more URNCST Journal articles and submit your own today at: https://www.urncst.com

\section{Lower Division ( $1^{\text {st }}$ and $2^{\text {nd }}$ year students $)$}

Biomedical Sciences and Chemistry

Development of silica-encapsulated recombinant $\boldsymbol{E}$. coli for remediation of fracking-originated benzene Angela Dong, Adriana Fedorowycz, Ramy Gabarin, James Yu McMaster University, Hamilton, Ontario, Canada

Fracking can lead to groundwater and surface water contamination with chemicals that have harmful effects on human health, such as benzene. While bioremediation of contaminated sites using bacteria is a popular method of mitigating adverse health effects, it is difficult to have commonly-used, fracking fluid-resistant bacteria target one specific toxic chemical. We propose the creation of a recombinant, silica-encapsulated Escherichia coli bacteria that is modified to specifically target benzene for remediation and to survive a toxic environment contaminated by fracking fluid. Ligation of the recA promoter sequence with pUC19, followed by an ompC gene sequence fused to a GP1 binding peptide sequence, will modify the E. coli bacteria to enable absorption of benzene. Tests with ampicillin will ensure that the bacteria have been successfully recombined, as the pUC19 gene sequence contains ampicillin-resistance genes and non-recombinants will be killed off. Upon successful recombination, recombinant bacteria will be encapsulated in silica in order to improve benzene absorption and increase protection within environments that have been contaminated with fracking fluid. Finally, the silica-encapsulated, recombinant $E$. coli will be tested for effectiveness of benzene absorption.

Bioremediation of fracking: A novel hybrid biofilm system using synthetically engineered curli fibres Maggie Hou, Jennifer Lee, Keerthana Pasumarthi, Harshini Ramesh

McMaster University, Hamilton, Ontario, Canada

Hydraulic fracturing, a popular mining technique, generates heavy metal contamination in nearby freshwater aquifers. This poses a threat to both the surrounding ecosystems and human health if exposed. Existing methods of heavy metal removal can produce additional hazardous byproducts. This paper proposes the use of a hybrid biofilm filter containing graphene and curli fibers with metal binding sites. Curli fibers are amyloid fibrils found on the extracellular biofilm of Escherichia coli (E coli.) Through use of plasmid vectors, E. coli will be engineered to produce secreted curli fibers with attached CS3 Pili. While CS3 Pili is capable of metal binding, the stability and adhesive properties of the curli fibers allows it to reliably hold on to the graphene scaffolding. With the filtration design and various experimental controls proposed, this model is ready for empirical proof of concept and subsequent quantitative optimization.

Engineering a robust microorganism for bioremediation of fracking flowback

Pranipa Ernest, Farheen Khan, Jenny Yune

McMaster University, Hamilton, Ontario, Canada

$P$. putida has been identified as a species of bacteria capable of degrading toluene and BTEX isomers from contaminated water. Although it is excellent for decontamination, it is incapable of surviving in fracking flowback conditions - a fluid filled with hazardous substances that may potentially leak into drinking water aquifers. This proposal suggests to genetically engineer the gene responsible for the degradation of toluene in Pseudomonas putida into an extremophilic organism, Thermococcus litoralis, to degrade toluene and BTEX isomers found in fracking flowback fluids.

The viability of biocide resistant methanotrophs as a solution to high concentrations of methane emissions from the soil of fracking sites

Sarah Fu, David Kim, Gene Liang, Darren Tran

McMaster University, Hamilton, Ontario, Canada

One approach of removing the excess methane in soil due to fracking is by introducing methanotrophs, a type of bacteria that will eliminate methane by metabolizing it into harmless products. However, due to the biocides in fracking fluid used to keep other bacteria from interfering with fracking, methanotrophs are unable to survive in contaminated soil sites. This application will present an experiment with the goal of growing a methanotroph culture that can not only survive, but also be able to 


\section{UNDERGRADUATE RESEARCH IN NATURAL AND CLINICAL SCIENCE AND TECHNOLOGY (URNCST) JOURNAL}

Read more URNCST Journal articles and submit your own today at: https://www.urncst.com

metabolize methane in a sample of contaminated soil. The hypothesis of our research is that raising concentrations of Pseudomonas fluorescens TN4 plasmid injected methanotrophs in soil contaminated by quaternary ammonium compounds (QACs), alkyldimethylbenzylammonium chloride (BAC), and methane, the concentration of atmospheric methane will decrease due to the methane metabolizing ability of methanotrophs.

\section{The effect of varying concentration of bacteriophages on sulfidogen populations}

Daniel Cui, Matthew So, Chris Tan, Kevin Zhao

McMaster University, Hamilton, Ontario, Canada

Sulfate-reducing bacteria, which produce hydrogen sulfide, represent a serious issue facing the fracking industry. Hydrogen sulfide poisoning is responsible for severe health risks to workers on fracking installations and residents near sites. Hydrogen sulfide in fracking wastewater also corrodes pipes, causing significant financial losses. Our study aims to investigate whether it is feasible to reduce hydrogen sulfide emissions from wastewater by controlling the growth of sulfate-reducing bacteria with phages.

The proposed study explores the minimal phage concentration necessary to inhibit the growth of Halanerobium congolense, a primary sulfate-reducing bacterium, over fifteen days. $H$. congolense should be isolated in vitro by simple identification of its colony characteristics. A phage should be isolated by adding fracking wastewater filtrate to a colony of $H$. congolense. The phage should propagate through the colony of $H$. congolense, leaving behind a plaque of dead bacteria from which pure phage samples can be obtained. This process should be repeated multiple times, to ensure homogeneity of final phage samples.

Experimental samples of $H$. congolense, with standardized concentrations of iron and bacteria similar to that found in wastewater, should be exposed to concentrations of phage varying logarithmically from $10,000 \mathrm{pFU} / \mathrm{mL}$ to $0.1 \mathrm{pFU} / \mathrm{mL}$. After fifteen days of exposure to phage, $H$. congolense concentrations in these samples should be measured through serial dilution. Solutions with high concentrations of sulfate-reducing bacteria will appear black, whereas solutions with inhibited bacterial growth will appear clear. This will allow the concentration of bacteriophage needed to inhibit $H$. congolense growth to be qualitatively determined.

Benefits of using bacteriophages include the host-specificity of bacteriophages, which mitigates the risk of environmental damage. However, this host specificity requires the development of multiple strains of viruses to target different sulfatereducing bacteria species to reduce hydrogen sulfide emissions, which may be the subject of future research.

\section{Reducing methane emissions from hydrofracturing with methanotrophic bacteria} Samira Adus, Henry He, Zameer Mukri, Sharif Natheir

University of Western Ontario, London, Ontario, Canada

Although the bulk of methane $(\mathrm{CH} 4)$ released in the process of hydrofracturing is harvested as an energy source, some escapes into the atmosphere and surrounding aquifer. Methane can trap radiation and contributes to the greenhouse effect when it accumulates in the atmosphere. Methanotrophic bacteria are capable of generating energy by breaking down methane into carbon dioxide (CO2), a much less potent heat-trapping gas relative to methane. This study proposes purifying air and water sources that have high methane concentrations as a result of hydrofracturing, through the use of the methanotrophic bacterium Methylococcus capsulatus (M. capsulatus) Foster and Davis. Methylococcus capsulatus can be used to break down methane that escapes from fracturing before reaching the atmosphere or underground water. By applying this bacteria as a coating on the steel exterior of the fracturing piping system, it may be possible to decrease methane emissions. To test this hypothesis, we propose a simulation model that imitates the environment caused by hydrofracturing to determine if methanotrophic bacteria can significantly decrease methane emissions.

\section{"World's toughest bacterium" joins the fight against fracking flowback water contamination Sukhman Brar, Rong xuan Zang University of Western Ontario, London, Ontario, Canada}

Recent studies done by the Environmental Protection Agency has shown that human drinking water is being contaminated with toxic compounds such as toluene and $\mathrm{Hg}$ (II) that is coming from the flowback fluid generated during fracking. A potential solution to this problem is the use of Deinococcus radiodurans in the bioremediation of toluene and $\mathrm{Hg}$ (II). On its own, this species of bacterium is resistant to radiation and can live in conditions of extreme $\mathrm{pH}$, temperature and nutrient 
UNDERGRADUATE RESEARCH IN NATURAL AND CLINICAL SCIENCE AND TECHNOLOGY (URNCST) JOURNAL Read more URNCST Journal articles and submit your own today at: https://www.urncst.com

deficiency. Furthermore, past studies have successfully transformed $D$. radiodurans with toluene and mercury metabolizing genes. Thus, D. radiodurans will be introduced into a high salt, toluene and $\mathrm{Hg}$ (II) containing a model of fracking flowback water. Using mass spectroscopy and mass liquid chromatography, levels of toluene and $\mathrm{Hg}$ (II) will be measured at different time points to assess the ability of bioremediation of $D$. radiodurans.

Determining the synergistic effect of Lentinula edodes and $\mathrm{N}$-alkanoyl-N-methyl-1-glucamine in mycoremediation Ivy Deng, Gary Foo, Wilson Ho, Jeremy Wu

University of Western Ontario, London, Ontario, Canada

Hydraulic fracturing is the injection of high-pressure fracking fluid, consisting primarily of water, into shale rock to release natural gases, brine and petroleum. The pollutants created from this technique, such as polycyclic aromatic hydrocarbons (PAHs) and heavy metals, are carcinogenic and severely damage our ecosystem. Fortunately, fungi have the ability to absorb and degrade these contaminants in a process known as mycoremediation. When coupled with surfactant micelles, the rate of mycoremediation greatly increases. However, over long periods of time, the surfactants interfere with the fungus' enzymes and transporter proteins, thus reducing its ability to remove contaminants. In our research proposal, we aim to investigate the synergistic effect and toxicity of a novel and natural surfactant, N-alkanoyl-N-methyl-1-glucamine when coupled with Lentinula edodes, a strain of white rot fungi. This polyol surfactant is a derivative of glucose, suggesting that it can be readily metabolized by microorganisms that use glucose as a source of energy. L. edodes cultures will be treated with $\mathrm{N}$-alkanoyl-Nmethyl-1-glucamine as well as fluorene, benzo[a]pyrene, and anthracene and allowed to incubate. Growth yield for mycelial cultures treated with the polyol surfactant is indicative of the potential toxicity of the surfactant on L. edodes. Yield of the PAHs would provide a comparison of bioaugmentation on the oxidation of PAHs. The results would provide insight into the viability of polyol surfactants on mycoremediation.

The cognitive impact of silica sand exposure on hydraulic fracturing workers

Zahra Anwar, Tanzeel Chowdhary, Mariam Khalid, Barira Siddiqui,

University of Toronto Scarborough, Toronto, Ontario, Canada

The process of hydraulic fracturing is used internationally with the aim of releasing gas and oil. This process has raised many concerns in regards to environmental and health impacts. This paper investigates the impact of exposure to silica sand which is used during the fracking process. The link between mild respiratory obstructions caused by silica sand overexposure and white matter impairment due to decreased oxygen levels in the brain is examined by comparing fracking workers and nonworkers. Participants are to be tested using High Resolution Computed Tomography to examine mild lung impairment due to constant silica exposure. The use of Diffusion Tensor Imaging is proposed in order to identify the effect of mild lung impairment on white matter pathways in the brain. Furthermore, the overall impact of cognitive impairment in fracking workers is to be assessed by comparing worker and non-worker performance on the Mini State Mental Examination. This study seeks to examine the cognitive wellbeing of fracking workers. Gradual cognitive impairment is not as evident as physical impairment and is therefore commonly neglected in research. However, cognitive wellbeing is vital to a better quality of life and is therefore a highly significant issue that requires further examination.

\section{Evaluating various methods for the degradation of nonylphenol in hydraulic fracturing fluid Justen Choueiry, Antony El-Khoury, Emmanuel Nassrallah, Justin Thomas University of Ottawa, Ottawa, Ontario, Canada}

Nonylphenol, an endocrine disrupting chemical, is a component of the fracking fluid used in hydraulic fracturing and often leaks into groundwater sources. This hazardous chemical binds to estrogen receptors and acts as an androgen antagonist, leading to several potentially lethal health effects. Electrochemical oxidation, direct photolysis and photoelectrocatalytic oxidation are techniques that utilize UV radiation and/or electricity in order to degrade nonylphenol. There are several variables that can greatly affect the efficiency and magnitude of the degradation such as: $\mathrm{pH}$, temperature, photocatalyst, photon flux and duration of UV exposure. Additionally, capillary gas chromatography / mass spectrometry can be used to quantify the chemical content of the experimental samples. This proposal seeks to find an optimized and practical technique for the degradation of nonylphenol that can realistically be integrated into the hydraulic fracturing process. We propose to use a baseline for each factor based on existing literature and varying each factor independently while observing the effect on the time it takes to degrade nonylphenol. We will also test each treatment process individually, so as to further isolate an

Bajwa et al. | URNCST Journal (2018): Volume 2, Issue 3

DOI Link: https://doi.org/10.26685/urncst.47

Page A4 of A20 
UNDERGRADUATE RESEARCH IN NATURAL AND CLINICAL SCIENCE AND TECHNOLOGY (URNCST) JOURNAL Read more URNCST Journal articles and submit your own today at: https://www.urncst.com

optimized procedure. Lastly, to avoid any unforeseen side-effects of the optimized procedure, we will be utilizing a mock sample of fracking fluid with nonylphenol absent, as a negative control.

\author{
Microbial methane oxidation by methanotrophic biofilters \\ Soumaya Awaleh, Lauren Couvrette, Natasha Maher \\ University of Ottawa, Ottawa, Ontario, Canada
}

The uncontrolled migration of methane, a potent greenhouse gas, during hydrofracturing is one of the major challenges of the natural gas industry. The proposed study will investigate the use of biofilters consisting of methanotrophic microorganisms as a way to mitigate methane emissions from hydrofracturing wells. Methanotrophs, or methane oxidizing bacteria, use methane as their only source of carbon and energy. These bacteria are ubiquitous, diverse and many are found in extreme environments. They are particularly appealing as bioremediation agents in methane-containing environments, since their primary enzymes have a broad substrate range that can transform various hydrocarbons including aromatic compounds. The present study will evaluate the bioremediation potential of Methylosinus trichosporium OB3b and Methylomonas sp. DH-1 in polluted sites such as hydrofracturing wells. These methanotrophs readily convert methane into methanol, a valuable raw material for a plethora of synthetic hydrocarbon products, when the enzyme methanol dehydrogenase is inhibited. This experiment will measure the rate of methane-to-methanol conversion in conditions simulating the environment within the upper portion of a hydrofracturing well (i.e., low oxygen levels and exposure to non-methane volatile organic compounds) in order to determine which species of methanotroph is more efficient. Additionally, it will explore the optimum gas levels (ratio methane:oxygen) for the conversion of methane to methanol for both species.

\author{
The future of fracking: Zeolites \\ Shawna Kim, Ambre Lambert, Rachel Miller, Anmol Saxena \\ Queen's University, Kingston, Ontario, Canada
}

Hydraulic fracturing has become a very popular method of extracting natural gas. Even though there has been an increase in fracking activity, fugitive emissions like methane and hydrogen sulfide are escaping more frequently, creating health hazards. This application will focus on an effective method of reducing these fugitive emissions based on a very unique proposal: using molecular sieves or zeolites to capture methane and hydrogen sulfide molecules. We propose running laboratory trials with zeolites that have an affinity for methane and hydrogen sulfide molecules, to examine their effectiveness.

The use of Candidatus Methylomirabilis oxyfera to reduce methane levels in groundwater resulting from flowback fluid contamination Zahin Hafiz, Moina Malek

University of Toronto Scarborough, Toronto, Ontario, Canada

Hydrofracking is a technique that allows for the extraction of natural gas and oils by the use of pressurized liquid. Although effective in performance, there have been several accounts of groundwater contamination due to the leakage of flowback fluid (fracking waste). As a result, methane and other volatile organic compounds (VOC) are transferred from flowback fluid to surrounding aquifers, and then into drinking water. This presents both environmental and health hazards. This problem can be rectified by the incorporation of methanotrophs such as, Candidatus Methylomirabilis oxyfera, in flowback fluid which have the ability to oxidize methane and VOC to less threatening compounds. Our proposal involves simulating the underground environment to observe the behavior of methanotrophs (4000 feet below the surface of the Earth) with the use of two distinct techniques which are gas chromatography and GFP technology.

The use of Methylococcus capsulatus treated with fomepizole in converting gaseous methane into methanol to reduce the harmful effects of methane produced as a result of hydrofracking

Umer Haider, Wei Hu

University of Ottawa, Ottawa, Ontario, Canada

Hydrofracking is used to extract natural gas from the ground with deep vertical, followed by horizontal drilling. This extraction method entails a process whereby water treated with fracking chemicals i.e. acids, salts, and other propants

Bajwa et al. | URNCST Journal (2018): Volume 2, Issue 3

DOI Link: https://doi.org/10.26685/urncst.47

Page A5 of A20 
UNDERGRADUATE RESEARCH IN NATURAL AND CLINICAL SCIENCE AND TECHNOLOGY (URNCST) JOURNAL Read more URNCST Journal articles and submit your own today at: https://www.urncst.com

(material that will prevent fracture closure) is pumped at high pressures through an array of special triplex and quintuplet pumps. These pumps propel the water into previously induced fractures by piston systems, which horizontally induce discontinuity in the bedrock above and below the horizontal arm. Large enough fractures allow the backflow of natural gas, which is often thoroughly collected. Components that compose natural gas consist of methane, propane, and traces of butane. When analyzed, $90 \%$ of the molecular composition of natural gas is attributed to methane. When there is leakage of natural gas (which is frequent; $30 \%$ of U.S. wells are leaking), there is methane pollution in the atmosphere. Methane is a non-polar, volatile organic compound; gas at room temperature, that is 28-36 times more efficient in trapping heat than carbon dioxide. Although the single-carbon gas lingers for a time period of 12 years, compared to the 200 years required for carbon, the high efficiency of its ability to trap heat correlates to recent spike in temperatures due to global warming. Methane itself is not immediately toxic to the human body, however, sunlight converts methane into formaldehyde, which induces damage to upper respiratory tract and is found to cause rhinitis. Short term exposure to formaldehyde results in the burning sensations of the eyes, nose, and throat; coughing; wheezing; nausea; and skin irritation. Methane produces 50\% the carbon dioxide as coal when burned making it an efficient fossil fuel, but the extraction process of methane is the true source of emission due to the intentional and unintentional dumping of molecular methane gas (CH4) in the atmosphere. This paper aims to demonstrate the ability of methanotropic bacteria Methylococcus capsulatus treated with a drug (fomepizole) to inhibit an enzyme; Alcohol Dehydrogenase (ADH), and using Copper (II) Oxidate to increase the presence of an enzyme; methane monooxygenase (pMMO), which will catalyze the reaction of methane $(\mathrm{CH} 4)$ into liquid methanol $(\mathrm{CH} 3 \mathrm{OH})$. Fomepizole is used to prevent the conversion of desired product methanol into formaldehyde by the bacteria. The purpose of the following proposal is to efficiently process methane and all its harmful effects into a fossil fuel; methanol, which is easily transported while producing less carbon dioxide than coal.

\section{$\underline{\text { Biology }}$}

Natively-induced hydrofracturing phytoremediation through hyperaccumulative arsenic-binding particles of tomato mosaic virus

Yoo K. Hong, Julie Huynh, Yun-Kyo Kim, Michael K. I. Lee

University of Toronto St. George, Toronto, Ontario, Canada

Hydrofracturing is a pressurized fluid-based method of deep-rock stimulation used to facilitate the release of trapped natural gas and petroleum. Arsenic contamination of water, a common by-product of hydrofracturing, is associated with numerous health and ecological concerns. Recent phytoremediation research has identified candidate plants capable of resisting and storing high concentrations of heavy metals within their tissue. Termed hyperaccumulators, recent work has been targeted at identifying the underlying "hyperaccumulation genes" in the interest of developing transgenic phytoremediation approaches. While identification has been successful, large-scale applications have yet to be conducted due to ethical and ecological barriers. Here, we propose the use of viral vectors to confer hyperaccumulation properties to native flora affected by hydrofracturing in a non-transgenic manner. Tomato mosaic virus (ToMV) is a non-retroviral RNA Tobomovirus capable of being engineered to produce fusion coat proteins. Through insertion of a PvACR2 hyperaccumulator gene, we construct a ToMV that facilitates production of arsenic-binding particles in target hosts. Thus, infected hosts are capable of hyperaccumulative behaviour by sequestering arsenic inertly within the cytosol. Through further modification with ToMV resistance genes and Pumilio and FBF (PUF) RNA binding proteins, we induce species selectivity within our ToMV construct such that conferred hyperaccumulation is specific to Arabidopsis thaliana. Finally, we take advantage of the high environmental stability of ToMV, using direct irrigation methods to confer hyperaccumulative activity to the native flora of hydrofracturing sites. Our approach is expected to yield reduced arsenic contamination in surrounding water and soil while remaining ecologically non-detrimental and largely reversible.

\section{Optimization of canola (Brassica napus L.) biodiesel production in puroindoline-expressing cultivars to minimize hydraulic fracturing practices \\ Yixin Jiang, Elena Kum, Peter Lee, Kathy Yu \\ University of Western Ontario, London, Ontario, Canada}

Hydraulic fracturing accounts for such a significant proportion of the world's petroleum and natural gas supply that replacing or modifying this productive technique would insufficiently meet energy demands. Instead, we propose to reduce reliance on fossil fuels derived from hydraulic fracturing by optimizing production of Brassica napus L. (canola) biodiesel, a 
domestically-produced, sustainable and environmentally friendly energy source. Canola biofuel needs to be producible in sufficient quantities, making a meaningful impact on energy demands, while also being competitively priced compared to fossil fuels in order to supplement hydraulic fracturing. Our objective is to improve canola biodiesel production by using puroindolines, lipid-transfer proteins shown to confer increased grain softness and plant oil yield. Softer grains reduce the cost of biofuel extraction associated with oilseed crushing while improved oil yields increase net biofuel production per crop mass. Two isoforms of puroindoline, puroindoline-a (Pin-a) and puroindoline-a (Pin-b), will be tested by addition of their respective genes (Pin-a and Pin-b) to canola plants to determine if their oil yields will be greater than that of wild-type canola. This novel strategy to create puroindoline-expressing canola cultivars may be a viable substitute for conventional fuels requiring hydraulic fracturing.

\section{$\underline{\text { Engineering }}$}

Application of methane-filtering-biocement in casing systems of oil wells Joshua Fedurko, Jean Napenas, Ray Ong, Sanjay Veerasammy University of Waterloo, Waterloo, Ontario, Canada

Hydraulic fracturing is a massive industry in Canada with over 175,000 oil and gas wells stimulated. Although an efficient process, hydraulic fracking takes a large toll on the environment. The current cement used in the fracking process leaves structural weak points that are prone exposing harmful chemicals into soil, aquifers and the surface. To reduce the environmental impact of this process, we are proposing adding methane-oxidizing and calcium bicarbonate-producing microorganisms to the cement/casing systems to provide better structural support and reduce methane emissions. The proposed experiment will test the structural strength, methane-filtering capabilities, and growth rate of the biocement/casing system to assess feasibility.

\section{Supercritical CO2 as fracking fluid potential for greener, water-less hydraulic fracking} Hiam Debsi, Shauna Han, Lin Kandakji, Zaid Karaki University of Ottawa, Ottawa, Ontario, Canada

Improving the efficiency of mechanical processes constantly challenges engineers as it requires the simultaneous optimization of yield and minimization of damages. This can be seen in the case of hydraulic fracturing, or fracking, where it is important to maximize oil and natural gas extraction while minimizing damage to both health and the environment. Many research regarding fracking look into replacing water with supercritical carbon dioxide (scCO2), an environmentally-friendly and financially feasible substitute.

Radionuclides in hydrofracturing groundwater Emilie Aloeristok, Samuel De Grace, Julia Guo, Brianna Wood University of Ottawa, Ottawa, Ontario, Canada

In light of increasingly growing concerns about the planet's environmental fortitude and lack of sustainable resources, oil pollution has been brought to the forefront as a major issue. Hydrofracturing, a common extraction method for this limited resource, negatively impacts the environment in many ways. It causes fissures within the soil underground, which deposits harmful amounts of possibly radioactive particles into groundwater. These radionuclides, most commonly found as radium, often cause major health problems with long term exposure to an infected source of underground drinking water. To negate the harmful effects of radionuclides in water caused by hydrofracturing, we propose to use a tested process called ion exchange at a municipal level in water filtration centers to remove any excess contaminants. We hypothesize that through the use of an ion exchange filtration system, the radium isotopes will be filtered out of the groundwater, reducing the amount of negative health effects. 
UNDERGRADUATE RESEARCH IN NATURAL AND CLINICAL SCIENCE AND TECHNOLOGY (URNCST) JOURNAL Read more URNCST Journal articles and submit your own today at: https://www.urncst.com

Taking the hydro out of hydrofracturing: Application of ultra-light weight proppants to cryogenic liquid nitrogen as a fracturing fluid

Amna Ahmed, Amna Majeed, Teresa Zhu

University of Toronto St. George, Toronto, Ontario, Canada

In the last decade, hydraulic fracturing has rapidly gained popularity worldwide, emerging as the leading method of natural gas extraction in the United States. However, the practice remains controversial due to its contribution to greenhouse gas emissions and the contamination of freshwater used in fracturing fluids. Although waterless fracturing fluids have been developed, including those using $\mathrm{N} 2, \mathrm{CO} 2$, oil, and alcohol, their application has been limited largely due to reduced fracturing power. Recent research has demonstrated that cryogenic nitrogen may prove a viable alternative, if this issue is properly addressed. Addition of durable, lightweight proppants is one way to increase fracturing power. This study aims to investigate the effect of proppant addition on the fracturing capabilities of cryogenic nitrogen. Three ultra-lightweight proppants will be combined with liquid nitrogen and fracturing power will be measured using triaxial stress tests. This novel approach has not yet been explored and will open more avenues of research into sustainable and efficient fracturing using cryogenic nitrogen.

The use of ultrasonic energy to deaggregate nZVI clusters and improve its efficiency in the removal of arsenic in fracking fluid contaminated water

Victoria Barbeau, Kitty Chen, Kristy $\mathrm{Ng}$

University of Ottawa, Ottawa, Ontario, Canada

Hydraulic fracturing is a method of retrieving natural gas and oil from shale rock that is deep beneath the Earth. Highpressure injection of fracking fluid is used to form cracks deep in the rock formation. The remaining solution, known as flowback solution, is drawn back, along with the oil or gas collected from the fractures. The fracking fluid contains many harmful chemicals that can be detrimental to human health, especially arsenic. In 2013, arsenic levels of groundwater near Texas fracking sites were eighteen times higher than samples taken in areas without fracking. Such contaminants that eventually reappear in tap water can lead to arsenic poisoning over a long period of time. The use of nano zerovalent iron (nZVI) is very promising in its abilities to remove contaminants efficiently. However, nanoparticles aggregate when suspended in water due to their high surface area to volume ratio, causing colloidal instability. This hinders nZVI's abilities to remove non-biodegradable contaminants, especially arsenic. Ultra-sonication is another thriving process that can be applied to wastewater remediation, whereby ultrasonic frequencies can be used to deaggregate protein and particles. By implementing ultrasonic treatment when cleaning fracking fluid with nanotechnology, uniform dispersion of nZVI will be maintained, maximizing its efficiency in the removal of arsenic.

\section{Geology, Physical and Earth Sciences}

Suck it up: Reducing concentrations of hydrofracking contaminants in groundwater and soil via phytoremediation Elger Baraku, Benjamin Kelly, Hannah Mahoney, Markelle Morphet

McMaster University, Hamilton, Ontario, Canada

Hydrofracking involves the use of pressurized water and other compounds to extract natural gas. These compounds produce a prominent environmental threat. The proposed solution of phytoremediation is promising due to the phytoextraction, phytodegrading, and rhizofiltering effects of hyperaccumulating plants. In carrying out our experimental procedure, it is expected that hyperaccumulating plants will be able to reduce heavy metal and harmful organic compound concentration in the soil surrounding hydrofracking sites. We will test the growth and hyperaccumulating effectiveness of a variety of plants in two different soil types and a range of concentrations of heavy metals and related organic molecules found in soil near hydrofracking wells. This not only impacts the local environment, but can affect the health and even the economies of nearby residential areas. With these considerations in mind, we propose an experiment that will take another step towards preserving local communities and ecosystems. 
UNDERGRADUATE RESEARCH IN NATURAL AND CLINICAL SCIENCE AND TECHNOLOGY (URNCST) JOURNAL Read more URNCST Journal articles and submit your own today at: https://www.urncst.com

Investigating graphene oxide permeable reactive barriers for filtering groundwater contaminated from hydraulic fracturing

Zifeng An, Konrad Grala, Aakanx Panchal, Kunjan Trivedi

McMaster University, Hamilton, Ontario, Canada

Hydraulic fracturing, or fracking is a method of natural gas extraction which involves pumping a brine solution into the ground to create a fracture that will allow natural gas to rise. However, one of the major concerns surrounding this method of natural gas extraction is that wastewater enters the groundwater supply, thereby contaminating it. This wastewater contains toxic materials such as heavy metal ions, radionuclides and other salts and organic compounds in high concentrations. Some of these materials are carcinogenic and thus a concern to human life and the environment.

The current solution involves the use of a zerovalent iron (ZVI) permeable reactive barrier (PRB) to filter out these toxic substances. However, it causes more fouling due to the accumulation of mineral precipitates and therefore is not very effective. The recent development in nanotechnology may allow us to develop a superior water filter to prevent groundwater contamination. Therefore, a different PRB is suggested: featuring the use of solid graphene oxide, a nanomaterial with a superior sorption ability is proposed as a replacement for the system. The proposed experiment is to test the efficacy of a GOPRB compared to the traditional ZVI-PRB. By emulating the process of groundwater contamination and flow with common materials found in fracking wastewater, we can determine how much more effective the GO-PRB is than the ZVI-PRB.

Preventing air pollution of natural gases resulting from Hydro fracturing by replacing the cement and casing with tight sandstone

Caitlin Lovick, Navreet Pabla, Ella Pasin, Diming Zhu

University of Waterloo, Waterloo, Ontario, Canada

Our study looks at the environmental and health impacts of the natural gas leaks resulting from failures in hydrofracturing. These leakages are predominantly the result of surface blowouts, which usually occur because of a malfunction in the cementing and casing of the wellbore. We have suggested that replacing this with tight sandstone, which is of very low permeability, will reduce these leakages.

\section{Capacitive deionization and advanced oxidation processes for wastewater filtration Olivier Brandts-Longtin, Keshav Goel, Amit Scheer, Dylan Singh \\ University of Ottawa, Ottawa, Ontario, Canada}

Unconventional oil and natural gas extraction techniques have recently enabled the exploitation of vast reserves of previously inaccessible resources. Hydraulic fracturing (fracking) facilitates natural gas extraction from underground reservoirs by pumping a highly pressurized mix of water and other compounds into shale rock to create fissures through which gas is released. While significant economic benefit has resulted from the development and usage of fracking, the process has been associated with numerous severe environmental and health consequences. Of particular concern, fracking generates large volumes of contaminated wastewater, including flowback water and produced fluid, and which often contain large quantities of organic toxins, heavy metal ions, and radioactive isotopes. Inadequate and inefficient wastewater treatment strategies have led the fracking industry to inject billions of gallons of this wastewater into the ground each year as a disposal method. There is therefore an urgent need to improve decontamination processes to alleviate the negative environmental and health impacts of fracking. A synergistic wastewater treatment process using $\mathrm{TiO} 2$ photocatalysis to mineralize toxic organic compounds by UV light exposure (advanced oxidation processes), followed by capacitive deionization to remove heavy metal ions and radioactive nuclei through adsorption on parallel graphene sheets, is herein described. The entire decontamination strategy would operate as an inline flow-through process and would be self- contained and portable. By implementing this coupled wastewater purification alongside fracking operations, rapidly and effectively purifying water from organic and ionic toxic impurities, fluid reuse would be enabled and the environmental impact of large volume ground injections could be minimized. 
UNDERGRADUATE RESEARCH IN NATURAL AND CLINICAL SCIENCE AND TECHNOLOGY (URNCST) JOURNAL Read more URNCST Journal articles and submit your own today at: https://www.urncst.com

\author{
Effective fracking with the Candidatus frackibacter \\ Marie-Pier Dupuis, Valérie Grondin, Jo-Ann Khoury, Rebecca Murphy \\ University of Ottawa, Ottawa, Ontario, Canada
}

Fracking is a problematic oil and gas extraction process with many negative effects on humans as well as ecosystems surrounding fracking sites. To attempt to alleviate the negative effects of fracking, a biological approach can be used to make it more efficient. Research has discovered Candidatus Frackibacter, a microbe living in the deep layers or rocks where fracking occurs. It has able to form and maintain stable ecosystems for many years, as it is already adapted to the extreme conditions imposed on these areas by fracking. These microorganisms can be genetically modified to release large amounts of rhamnolipids by incorporating into their plasmids, genes from bacteria that produce a high amount of rhamnolipids. Rhamnolipids, a biosurfactant, increase the porosity of the shale rocks by decreasing the interfacial tension between the rock and the oil to augment hydrocarbon mobilization. With an increased porosity, these rocks can allow for a larger flow of oil and gas. They can also fracture more easily if submitted to high pressures and water flow. As a result, less pressure, chemicals, and water will be needed to break through the shale layers. Consequently, the toxic effects of the chemicals, the contamination of water, and the risk of stressing the bedrock, thus causing earthquakes, are all diminished.

The incorporation and efficiency of using electrocoagulation and microbial degradation system to remove contaminants from hydraulic fracturing flowback water

Juliahna Hill, Alexander Rigney

University of Ottawa, Ottawa, Ontario, Canada

Hydraulic fracturing, or fracking, is currently of major concern due to the environmental impact it has on its surroundings. The fracking fluid used contains many toxic compounds that seep into, and contaminate, the sur-rounding environment. To address this problem, we propose the use of a hybrid electrocoagulation and microbial degradation system to remove as much of the contaminants from flowback water as possible. We will thus test the efficiency of such a system, as well as the feasibility of being able to scale the system.

\title{
Global Health
}

Bivalve decontamination of hydraulic fracturing chemical pollutants in freshwater Ira Brown, Jonah Rakoff University of Western Ontario, London, Ontario, Canada

Chemical additives present in hydraulic fracturing fluid, also called fracking fluid, have been shown to have adverse health effects in humans. Water contamination as a result of hydraulic fracturing has also been observed. Water treatment facilities therefore require innovative techniques to remove the vast as-sortment of fracking chemicals present in contaminated drinking water sources. The natural filtration capabilities of freshwater bivalves could solve this problem if introduced to water treatment plant reservoirs. This study aims to test the efficacy of bivalve filtration of fracking wastewater using a series of water quality tests. If the results of the study indicate that bivalve activity leads to a significant decrease in the amount of harmful chemicals present in the water, bivalve use could be implemented as part of the water purification process. This preemptive decontamination measure would ensure safe drinking water remains available to communities in close proximity to fracking sites. Consequently, human disease associated with hydraulic fracturing chemicals may be prevented.

Keep your poison out of my water: Don't FRACK with cancer

Lisa Li, Jamie Thompson, Katelyn Tsang

University of Ottawa, Ottawa, Ontario, Canada

A major problem prevalent near fracking sites is the disposal of the fracking water into the nearby wastewater supply. The fracking fluid contains chemicals, many of which are toxic, which can contaminate the drinking water for residents nearby. Naphthalene, considered to be the most volatile polycyclic aromatic hydrocarbon (PAH), is found in fracking water and is known to negatively affect the respiratory, nervous, and reproductive systems for humans and animals near these fracking sites. Bioremediation is an effective way to degrade organic compounds into non-toxic products. The extraction and isolation of pure naphthalene from a sample of contaminated water using steam distillation, followed by the release of Starkeya

Bajwa et al. | URNCST Journal (2018): Volume 2, Issue 3

DOI Link: https://doi.org/10.26685/urncst.47

Page A10 of A20 
UNDERGRADUATE RESEARCH IN NATURAL AND CLINICAL SCIENCE AND TECHNOLOGY (URNCST) JOURNAL Read more URNCST Journal articles and submit your own today at: https://www.urncst.com

novella into the naphthalene to form a biofilm and degrade it to effectively yield safer $\mathrm{CO} 2$ and $\mathrm{H} 2 \mathrm{O}$ byproducts. This proposal will aim to reduce the incidence of DNA mutations and various forms of cancer, one of the leading global causes of death. Despite the successful removal of naphthalene from drinking water, considerations should be made towards the removal of other volatile organic compounds that exist in fracking water, as several others also possess chronic health implications.

The isolation and purification of heavy metal-binding microorganisms for use in the bioremediation of wastewaters from hydraulic fracturing

Saif Dababneh, George Liu

University of Ottawa, Ottawa, Ontario, Canada

With the rise of the use of fracking, and the chemicals associated with it, there has been a tremendous increase in frackingrelated diseases that have surfaced in the medical world. Chemicals released through fracking are considered environmental contaminants, and are rapidly making their way into agriculture, livestock, and even the air we breathe. Such concerns have lead scientists to look further into a solution that would decrease the concentration of such chemicals in the ecosystem, specifically heavy metals such as cadmium and arsenic. Luckily, some bacteria have developed some kind of resistance against heavy metals, and are even capable of degrading them.

Use of Corynebacterium glutamicium for methanol oxidation in contaminated local water Caitlyn Mourcos, Rahna Rasouli, Samantha Van Bommel

University of Ottawa, Ottawa, Ontario, Canada

The extraction of natural gas by means of fracking is a common practice in multiple countries worldwide. Due to the toxic fracking fluids used, many communities are at risk of having their water supply contaminated by many different chemicals, including methanol. Methanol is very dangerous, and often fatal when consumed, even in small quantities. We propose the use of Corynebacterium glutamicum, a common non-pathogenic soil bacterium (often consumed via fruits and vegetables), to create a methanol degrading product that can be used at home. C. glutamicium can endogenously oxidize methanol into carbon dioxide. Our experimental methods will determine the amount of bacteria needed for the varying concentrations of methanol in contaminated water in order to safely and reliably remove methanol from the water for consumption. The bacteria will be freeze dried into a powder which will be stored in a gelatin capsule along with glucose (for growth). The bacteria will then be filtered out by a common mechanical filter (perhaps incorporated into a Brita ${ }^{\circledR}$ type filter). This method offers an entirely natural, non-toxic, and environmentally friendly way to easily decontaminate water. The bacteria are found in soil, and even the fruits we eat. The only extra additive will be sugar, which will be primarily metabolized by the bacteria before consumption. We hope to make this inexpensive, sustainable, and most importantly, environmentally friendly and safe method of methanol extraction available to the affected communities worldwide.

\section{Mathematics and Physics}

Bifunctional electrodes in tangent with electrodeionization: Innovative approach to flowback treatment Mia Cadieux, Jay Chen, Brooke Davidson, David Sahai

University of Guelph, Guelph, Ontario, Canada

Hydraulic fracturing is a technique used for the extraction of oil from beneath ground. Although it provides an efficient form of harvesting natural resources, fracking comes with negative effects, particularly the contamination of drinking water. This water, known as flowback, is predominantly composed of water with traces of dangerous chemicals such as hydrocarbons, heavy metals, salts and radioactive materials. With fresh water supplies becoming scarce, it is important to innovate ways to conserve the natural resource. However, treating these high levels of total dissolved solids (TDS) can be difficult and expensive. The proposed idea is to utilize electrochemical methods to eliminate the pollutants within the flowback in an efficient, reusable and cost-effective manner. This will be done through an electrochemical process, specifically with the use of bifunctional electrodes and electrodeionization. The use of bifunctional electrodes is driven by both photocatalysis and electrocatalysis which allows for the deposition of heavy metals. Following this, electrodeionization combines electrodialysis and ion exchange to separate the wastewater into one dilute solution and two concentrated solutions, dramatically reducing the level of salts and radioactive substances in the flowback. Following these processes, the fluid can be immediately reused 
UNDERGRADUATE RESEARCH IN NATURAL AND CLINICAL SCIENCE AND TECHNOLOGY (URNCST) JOURNAL Read more URNCST Journal articles and submit your own today at: https://www.urncst.com

for fracking. This provides a unique approach to battling water contamination while considering chemical, sustainable, and socio-economic factors.

\title{
Upper Division $\left(3^{\text {rd }}\right.$ year and above students)
}

\section{Biomedical Sciences and Chemistry}

\author{
Optimization of reverse osmosis flowback water treatment using halotolerant microbes naturally enriched in \\ fractured shales \\ Mark Cahalan, David Moskal, Cimon Song, Jianhan Wu \\ McMaster University, Hamilton, Ontario, Canada
}

Flowback water recovered after hydraulic fracturing operations poses a serious environmental concern due to the sheer quantity produced and its toxic chemical composition. Traditional methods of wastewater treatment cannot be used for flowback water treatment due to its high concentration of non-biodegradable dissolved solids. Consequently, alternative technology has been developed to address this problem. Reverse osmosis (RO) treatment is one such example. However, guar gum gelling agents found in flowback water impede membrane permeability and water flux rate of RO, consequently decreasing the efficiency and practicality of this desirable, environment-friendly technology. Previously, a biological solution using activated sludge to degrade guar gum prior to RO treatment was attempted with limited success due to the inhibitory effects of hypersalinity (characterized by high total dissolved solids content) on microbial activity. To solve this problem, several recently discovered strains of bacteria and archaea found to be naturally enriched in fractured shales may be utilized through genetic modification to degrade guar gum under hypersaline conditions. These microbes are naturally halotolerant and thrive under hypersaline conditions, making them prime targets for genetic modification targeting various chemical additives in flowback water. Here, we provide a proof of concept model using these microbes to selectively target guar gum degradation to improve the efficiency of RO treatment.

\author{
The application of genetically engineered Pseudomonas aeruginosa in the degradation of polycyclic aromatic \\ hydrocarbons \\ Yaqiong Ren, Annie $W u$ \\ McMaster University, Hamilton, Ontario, Canada
}

Fracking, the use of hydraulic pressure to extract natural gas and oil from the ocean floor, has significant effects on human and environment health. Specifically, polycyclic aromatic hydrocarbons (PAH) released from fracking is associated with immunosuppression and carcinogenic effects. Bioremediation, the use of microbes to treat contamination, is an efficient and cost-effective method of PAH removal. The formation of bacterial biofilms, an aggregation of cells enclosed in a polymeric extracellular matrix, is a naturally-occurring phenomenon that significantly improves bioremediation efficiency through the promotion of bacterial resilience and the secretion of surfactants that can emulsify hydrophobic substances. Biofilm formation is typically regulated by cell density. However, the 2-heptyl-3-hydroxy-4(1H)-quinolone (PQS) signal molecule has been identified as a cell density-independent regulator of biofilm formation. Several research groups have demonstrated that the addition of exogenous PQS protein upregulates biofilm formation. We have designed a PAH-inducible plasmid for the transformation Pseudomonas aeruginosa (P. aeruginosa), a bacterial strain implicated in the metabolism of select PAH. The genetically engineered strain of $P$. aeruginosa overexpresses the PQS protein. We propose that the overexpression of PQS enhances biofilm formation and the biodegradative efficiency of $P$. aeruginosa. The successful development of a genetically engineered strain of $P$. aeruginosa may contribute to bioremediation efforts and pollution clearance to reduce human and environmental health consequences associated with the fracking. 
UNDERGRADUATE RESEARCH IN NATURAL AND CLINICAL SCIENCE AND TECHNOLOGY (URNCST) JOURNAL Read more URNCST Journal articles and submit your own today at: https://www.urncst.com

\author{
Impacts of drinking water contaminated with hydraulic fracturing flowback and produced water on oxidative stress \\ in mice (Mus muculus) \\ Yu Min Liang, Avinash Pandey \\ University of Western Ontario, London, Ontario, Canada
}

Hydraulic fracturing (fracking) is a process to free natural gas trapped in shale rock by pumping high pressure water, proppant and other chemical compounds into the earth at high pressure. This process is highly polarizing due to potential environmental risks. Fracking generates Hydraulic Fracturing Flowback and Produced Water (HF-FPW) which has been shown to contain high concentrations of heavy metals, radionuclides and hazardous and carcinogenic organic molecules. Research by the environmental protection agency (EPA) has shown a high risk for contamination of groundwater (and drinking water) with HF-FPW. Recent studies have also established that exposure to HF-FPW can lead to oxidative stress in Rainbow Trout. The impact of exposure to water contaminated with HF-FPW in mammals has yet to be assessed. This study examines the impact of drinking water contaminated with HF-FPW in mice (Mus Muculus). 45 mice were randomized to have a control group or 2 different treatment arms. The control group received clean drinking water while one treatment arm received water contaminated with $10 \% \mathrm{HF}-\mathrm{FPW}(\mathrm{v} / \mathrm{v})$ and the other treatment arm received water contaminated with $50 \%$ HF-FPW. Mice were exposed to the treatment for 1 week before they were euthanized. Their livers are then extracted and analyzed using the TBARS assay to quantify the effects of oxidative stress. As fracking grows increasingly important in energy production, this study provides crucial information about its potential impacts on the health of mice which can be extrapolated to humans.

Inhibition of microsomal epoxide hydrolase using valpromide to reduce carcinogenicity of polycyclic aromatic hydrocarbon (PAH) pollution released from fracking

Dana Brinson, Catherine Cellucci, Kritika Padala, Katelyne Schram

University of Ottawa, Ottawa, Ontario, Canada

Of the many issues that have resulted from hydraulic fracturing, the release of toxic pollutants into the air is one of the most severe. One of these pollutants includes polycyclic aromatic hydrocarbons (PAHs) which are chemical compounds released during fracking. Modification of these molecules in the body is carried out by the enzyme epoxide hydrolase (EH), which produces metabolites that may be mutagenic. If these metabolites are not excreted, they may be stored in adipose tissues resulting in serious health concerns. Valpromide, a competitive inhibitor, has been shown to successfully block microsomal $\mathrm{EH}(\mathrm{mEH})$ activity. This allows metabolites to bind to other conjugates, favoring excretion. Additionally, inhibition of mEH may result in a decreased rate of DNA adduct formation caused by PAHs. Formation of DNA adducts leads to mutations being induced into the DNA structure. The effectiveness of valpromide as a preventive measure will be tested through administration to mice that have been exposed to PAH levels similar to fracking sites. Mice who are null in mEH gene (mEH-/-) and wild-type (WT) mice will be compared using tissue, urine and blood samples for metabolites. In addition, their liver's will be harvested to isolate DNA and a 32P-postlabeling assay will be used to measure DNA adduct formation. If proven successful, the use of valpromide for $\mathrm{mEH}$ inhibition may act as a preventative measure for debilitating illnesses such as cancer. In environments with high PAH concentrations such as fracking sites, this treatment could become essential for the health of workers.

\title{
Anaerobic bacteria in permeable reactive barriers for the degradation of BTEX Florence Grenapin, Rim Al-Siss, Mariam Taktek, Si Yu Zhang University of Ottawa, Ottawa, Ontario, Canada
}

Natural gas is an inseparable part of modern life. With the depletion of easily accessed natural gas deposits, developers have turned to fracking shale to meet demand. The human and environmental impact of fracking cannot be understated. Hydrofracking involves pumping fluid into shale to release the gases trapped within; a process that uses a copious amount of water containing toxic chemicals such as Benzene, Toluene, Ethylbenzene, and Xylene (BTEX). Therefore, filtration of water targeting BTEX is crucial to reduce their amount escaping into the environment. Currently strains of bacteria found in nature have the metabolism to degrade benzene into non-toxic constituents such as carbon dioxide or water. These bacteria can be employed in a permeable reactive barrier (PRB) around the fracking well to degrade fluid that leaks from the well. This proposal aims to create a PRB that contains anaerobic bacteria that will degrade BTEX emerging from leaking fracking fluid to prevent the contamination of the surrounding environment.

Bajwa et al. | URNCST Journal (2018): Volume 2, Issue 3

DOI Link: https://doi.org/10.26685/urncst.47 
UNDERGRADUATE RESEARCH IN NATURAL AND CLINICAL SCIENCE AND TECHNOLOGY (URNCST) JOURNAL Read more URNCST Journal articles and submit your own today at: https://www.urncst.com

Nature, nurture and engineering: Pathways to bioremediation in soils affected by fracking flowback pollution Rania Belhadjhamida, Dirk Grebenc, Eesha Lodhi

Queens University, Kingston, Ontario, Canada

Most environmental studies about hydraulic fracturing (fracking) to date have focused on fracking's direct impact on water and air quality. However, the long-term impact of fracking development on the surrounding soil, and whether ecosystems can repair themselves, is not well understood. This proposal aims to study the impact of fracking spills on the soil microbiome, as this will give valuable information on the nature of the damage done and explore two avenues for bioremediation. We propose to simulate small flowback spills onto three soil samples: the native soil of the area; soil mixed with bacteria that are known to survive in and break down flowback fluid; and bacteria that have been engineered to clean the environment faster. DNA sequencing will be used to determine the concentration of native bacteria in the soil, and this will be used to infer overall soil health. This research will illuminate both how the native soil responds to fracking pollutants, while it also demonstrates potential pathways for environmental intervention and repair.

Harnessing the power of magnetic fields in the elimination of metallic and organic toxins from aqueous environments: magnetotactic bacteria as a novel bioremediation tool Abiraa Karalasingam, Parandis Kazemi, Viethushaa Mohandas, Olivia Rennie University of Toronto Scarborough, Toronto, Ontario, Canada

The expansion of hydrofracturing, an industrial technique used to extract natural gas and oils, has raised numerous concerns regarding potential risks on health and the environment. Given the urgency of eliminating toxic hydrofracturing by-products, multiple approaches are beginning to be investigated. Nanoparticles have the potential to absorb pollutants from aqueous solutions, decreasing the overall concentration and toxicity of the contaminant. However, some varieties of nanoparticles possess harmful properties that also have negative impacts on the environment. Other approaches of waste removal have considered exploiting intrinsic detoxification processes in microorganisms. Magnetotactic bacteria (MTB) have gathered increased attention in recent years for the unique capability of converting toxic metallic elements into nontoxic magnetic nanoparticles. Consequently, metallic nanoparticles from MTB have been suggested to facilitate detoxification of organic toxins. Here we purpose an environment-friendly, low-cost model to remove metallic and organic pollutants from the water efficiently. We present a genetically modified version of MTB that not only is capable of converting metallic toxins into nanoparticles but also utilize those nanoparticles to enhance the detoxification of organic toxins within the same closed system. Finally, given the magnetic properties of these nanoparticles, magnetic fields may be used for extraction and by extension, purification of the initial solution.

Bioremediation in the removal of polycyclic aromatic hydrocarbons from fracking wastewater Elshaimaa Abdella, YiQin Cheng, Alison Donald, Saumya Surti

University of Toronto St.George, Toronto, Ontario, Canada

Although fracking is a method used worldwide to obtain natural gas, it has been labelled as a controversial practice as it produces large-scale environmental and health hazards. Flowback Produced water (FPW) is a major concern of hydraulic fracturing due to its high levels of total dissolved solids (TDS), metals, radioactive minerals from underground, and polycyclic aromatic hydrocarbons (PAH). The wastewater resulting from fracking operations is either disposed of in deep injection wells or treated through a filtration system. Both methods come with their own environmental and health hazards, such as leakage into shallow aquifers and production of excessive amounts of solid waste, respectively. We propose the usage of a two-step bioremediation filtration system that could potentially convert the harmful PAHs, into nontoxic end products and contribute to the field of Pseudomonas metabolomics. The first filter will contain saline-resistant Halophytes. This will optimize the environment for the second filter, which will contain Pseudomonas, naphthalene (PAH) metabolizing bacteria. This two-step filter will provide insight to the effectiveness of using Pseudomonas to work in a complex and realistic environment to degrade PAHs. 
UNDERGRADUATE RESEARCH IN NATURAL AND CLINICAL SCIENCE AND TECHNOLOGY (URNCST) JOURNAL Read more URNCST Journal articles and submit your own today at: https://www.urncst.com

\title{
$\underline{\text { Biology }}$
}

Biodegradation of polycyclic aromatic hydrocarbons and heavy metals in flowback water with silica-gel encapsulated Escherichia coli Betelehem Gulilat, Katharine Pacoli, Krisha Patel, Priyanka Savaliya University of Western Ontario, London, Ontario, Canada

Hydraulic fracturing (HF) is a common technique to recover gas and oil from shale rock by pumping high-pressure fluid into the ground. Although HF generates a majority of the world's natural gas supply, it has many detrimental effects on public health and the environment. HF is accompanied by the production of flowback wastewater, which contains contaminants including carcinogenic polycyclic aromatic hydrocarbons (PAHs) and toxic heavy metals. Currently, there is no effective method of treating flowback water, as it is traditionally disposed in evaporation ponds, potentially leading to dangerous spills into surface water and soil. Previous research has shown that successfully encapsulated Pseudomonas sp. strain NCIB 9816-4 expressing naphthalene dioxygenase (NDO) in silica-gel results in the biodegradation of PAHs in HF water. Furthermore, Pseudomonas aeruginosa has been discovered to have an effective heavy metal uptake pathway by secreting a chelating agent, pyoverdine (PvdI), and expressing ferripyoverdine (FpvA) transmembrane receptor. By expressing NDO, PvdI, and FpvA in silica-encapsulated Escherichia coli, we hope to develop a method to eliminate PAHs and heavy metals in HF water and thus reduce the health and environmental effects of fracking.

Inhibition of microsomal epoxide hydrolase using valpromide to reduce carcinogenicity of polycyclic aromatic hydrocarbon (pah) pollution released from fracking

David Brzezinski, Melodie Mallais, Robert Matson, Derek Meng

University of Ottawa, Ottawa, Ontario, Canada

Hydraulic fracturing is the industry standard for extracting hydrocarbons from shale formations. Although much attention has been paid to the economic benefits and environmental impacts of this process, little attempts have been done to recycle the resulting wastewater. Previous works have confirmed that wastewater reservoirs contain substrates that could support biogenic methane production, and even contain microbes from the methanogens family that are known to contain genomes coding for methanogenesis. However low yields of methane are observed at these ponds despite high concentrations of substrates. We propose that transformation of these microbes with genes encoding for key enzymes from the methanogenesis pathway, starting from methanol, would result in higher production of methane gas. It is our hope that potential for revenue will provide incentive for the hydraulic fracturing firms to invest in a solvable problem for wastewater recovery. It would also provide a proof of concept for removal of other contaminants prior to entry into a wastewater treatment plant using microorganisms.

\author{
Bioremediation of uranium in radioactive wastewater via genetic engineering Deinococcus radiodurans \\ Dorian Grey, Anandu Nair \\ University of Toronto Scarborough, Toronto, Ontario, Canada
}

The treatment of radioactive wastewater produced from hydraulic fracturing is an economically expensive process that requires excessive transportation of water to treatment plants. This transportation process also poses a significant environmental risk due to the high levels of radioactive toxins (Uranium and Radium) present in the water. This proposal investigates the possibility of an on-site (at the well) method of treatment that will minimize transportation costs using a bioremediation approach. By genetically engineering a strain of the extremophile, Deinococcus radiodurans, with the electroconductive pili inducing gene from another bacterium known as Geobacter sulfurreducens, we will attempt to engineer a microorganism capable of reducing radioactive uranium molecules present in frack water. This will serve as a more efficient treatment method by minimizing radiation exposure in the environment and greatly reducing expenses for fracking wastewater treatments. 
UNDERGRADUATE RESEARCH IN NATURAL AND CLINICAL SCIENCE AND TECHNOLOGY (URNCST) JOURNAL Read more URNCST Journal articles and submit your own today at: https://www.urncst.com

\author{
Rhizoremediation of polyaromatic hydrocarbon hydrofracking by-products with a transgenic rhizobia-legume \\ mutualism construct \\ Chris Knox, Daniel Li, Jing Wu, Shirley Zhong \\ University of Toronto St.George, Toronto, Ontario, Canada
}

Pioneered in 1947, the process of hydrofracking involves utilizing highly pressurized liquids to introduce cracks deep in the Earth, allowing previously trapped fossil fuels such as petroleum and natural gas to be extracted. Although beneficial regarding the growing demand for fuel, hydrofracking operations release large amounts of pollutants into the surrounding area. These include polyaromatic hydrocarbons (PAH) and volatile organic compounds (VOC), both of which are implicated in cancer and cardiovascular diseases. More specifically, VOCs are common environmental pollutants which persist long after operations cease, leading to prolonged negative environmental and health impacts. Bioremediation, the use of microbes in metabolizing harmful hydrofracking by-products, is a popular method of decontamination. However, the relatively new technique rhizoremediation, involving mutualism between transfected Rhizobia bacteria and plants, shows promise as it has several advantages over other techniques. For example, rhizoremediation ensures proper transgenic bacterial growth, allows degradation of contaminants deeper in the soil, and enables the modification of existing flora, which bypasses the issue of introducing potentially problematic foreign bacteria into the ecosystem. We propose the transgenic expression of TouA, an enzyme from Pseudomonas bacteria that metabolizes numerous VOCs, into Sinorhizobium meliloti, in order to form a more efficient VOC breakdown construct. The new TouA-expressing Rhizobia population will then be incorporated into a mutualistic construct with legumes from fracking sites to test viability.

\title{
$\underline{\text { Engineering }}$
}

Seal-\&-Heal®: a novel two-prong system to attenuate fracking-mediated groundwater contamination Yaanu Jeyakumar, Deeksha Kundapur, Kelvin Ng, Umaseh Sivanesan McMaster University, Hamilton, Ontario, Canada

As natural gas and oil become more difficult to access, the process of fracking is gaining momentum at an unprecedented rate. Accompanying this rise in popularity, a number of environmental, health, and safety risks have gained notoriety. One severe repercussion of increased fracking has been an elevation in groundwater contamination, primarily resulting from leaks in fracking-related infrastructure, including: fracturing wells, storage tanks, pits, and flowlines. To address these concerns, we propose Seal-\&-Heal@, a novel two-part approach, to attenuate groundwater contamination. The first component, HealTech®, is involved in regenerating cracked cement encasings of fracturing wells via microencapsulated sodium silicate. The second component, SealTech ${ }^{\circledR}$ will be introduced not only as an adjuvant to these fracturing wells, but also to structures involved in the storage and transportation of fracking wastewater. SealTech ${ }^{\circledR}$ involves double-layered, hydrogel-coated capsules containing sodium polyacrylate, which possesses the ability to immediately expand and seal leaks. Notably, SealTech ${ }$ is manufactured with the variability of each fracking structure in mind, imparting a degree of flexibility unique to this intervention that existing solutions have thus far been unable to produce. Overall, Seal-\&-Heal@ aims to provide a holistic, adaptable, and cost-sensitive method of combating the primary causes of groundwater contamination with respect to fracking infrastructure.

\author{
Reducing volatile organic compound emissions with a biofilter inoculated with synthetically engineered Escherichia \\ coli \\ Mihai Dumbrava, Cindy Kao, Daniel Lee, Inmo Sung \\ University of Western Ontario, London, Ontario, Canada
}

Various byproducts of fracking, such as methane gas, benzene, and other Volatile Organic Compounds (VOCs), have become a target for studies on health and environmental damage. These compounds are released during natural gas and petroleum extraction, and from the toxic residual water created from the fracking process. Although the long-term effects of some of these chemicals have yet to be determined, the elevated levels present in neighboring communities have been shown to cause an increase in the prevalence of acute respiratory, neurological, and reproductive diseases. In order to reduce the levels of these harmful airborne pollutants, we propose the creation of a biofilter inoculated with genetically engineered bacteria designed to metabolize VOCs and convert them into safer end products.

Bajwa et al. | URNCST Journal (2018): Volume 2, Issue 3

DOI Link: https://doi.org/10.26685/urncst.47 
UNDERGRADUATE RESEARCH IN NATURAL AND CLINICAL SCIENCE AND TECHNOLOGY (URNCST) JOURNAL Read more URNCST Journal articles and submit your own today at: https://www.urncst.com

Engineering E. coli curli fibers to straighten out the fracking problem: Sequestering lead from hydrofracturing contaminated water

Monica Chung, Clara Fikry, Shawn C. Receno, Shwetha Suresh

University of Waterloo, Waterloo, Ontario, Canada

Hydraulic fracturing is an unconventional method of oil and gas extraction that has been met with a combination of praise and disapproval. Through hydrofracturing, water resources can be compromised by unintentional release of toxic materials into the surrounding environment. Our project is focused on utilizing synthetic biology to minimize and prevent the harmful consequences of heavy metal residues in water. In particular, increased levels of lead in water produced by hydrofracturing will be filtered using a genetically engineered biofilm. We propose a novel water filtration system featuring a biofilm composed of modified curli fibers. These curli fibers can be engineered to sequester lead ions through the use of PbrR, a repurposed lead binding protein.

\section{Using optical properties to quantify BTEX concentration in blood}

Bingruo Liu, Adele Nikitina, Netra Unni

University of Toronto St.George, Toronto, Ontario, Canada

Hydraulic fracturing has evoked a significant number of health concerns due to the workers' long-term exposure to toxins. One of the most common toxins are volatile organic compounds (VOCs), including benzene, toluene, ethylbenzene and xylene (BTEX compounds). Although external monitoring devices of BTEX levels are commercially available, they fail to accurately reflect individual intake levels of the toxins. Hence, it is desirable to develop a wearable technology for fracturing workers to continuously monitor their BTEX levels in the body and take medical precautions as needed. Enlightened by wearable pulse oximeters that use light absorption of hemoglobin to detect changes in its concentration in blood, it is proposed that similar optical properties can be integrated to develop wearable BTEX monitors. This research project hypothesizes that significant changes in blood optical properties, including light absorption, refraction and scattering, can be observed under varying levels of BTEX concentration. The proposed method entails examining human blood samples with controlled concentrations of BTEX through Fourier transform infrared spectroscopy (FTIR), refractometry and dynamic light scattering (DLS). Despite the limited fidelity of the blood samples to an in vivo environment (i.e. lack of skin barrier, blood vessels, etc.), it has the potential to become the foundation of a wearable BTEX monitoring device. This device can use the aforementioned optical properties to continuously and noninvasively detect blood BTEX levels in fracturing workers. Future steps include investigating the effect of the skin barrier, determining personalized baselines, and designing an integrated sensor-receptor system easily wearable by the workers.

Evaluating polyacrylate-styrene copolymer (polyFAST) and benzoyl-vinyl acetate copolymer (polyBOVA) as possible thickening agents for $\mathrm{CO} 2$ fracturing fluid

Christopher Chan, Natalie Eng, Meor Hakeem, Crystal Liu

University of Alberta, Edmonton, Alberta, Canada

Hydraulic fracturing has been the conventional method of extracting hydrocarbons from shale formations. However, there is evidence to suggest that the process is detrimental to environmental and human health, mainly due to the chemical additives necessary for water-based fracturing fluid. Carbon dioxide fracturing, which uses a CO2-based fracturing fluid, has been proposed as an alternative that would eliminate the need for many of these chemical additives. However, the low viscosity and poor proppant carrying capacity of $\mathrm{CO} 2$ is a significant obstacle to using this technique. Proppants are essential to the fracturing fluid as they increase the permeability of rock formations, allowing for the extraction of hydrocarbons. For this method to be viable, the physical properties of $\mathrm{CO} 2$ fracturing fluids must be altered to improve their proppant carrying capacity. Based on previous studies, we propose an investigation of two polymers-fluoroacrylate-styrene copolymer (polyFAST) and benzoyl-vinyl acetate copolymer (polyBOVA) - as potential thickening agents to increase the viscosity of $\mathrm{CO} 2$ and to optimize its ability to transport proppants. Assessing the solubility, viscosity, and proppant transport performance of the CO2-polymer mixture using both experimental and computational methods will provide a clearer picture as to which of the two proposed polymers is most suitable. This work will contribute to the continuing development of a fracturing technique that aims to minimize its environmental impact.

Bajwa et al. | URNCST Journal (2018): Volume 2, Issue 3

DOI Link: https://doi.org/10.26685/urncst.47 
UNDERGRADUATE RESEARCH IN NATURAL AND CLINICAL SCIENCE AND TECHNOLOGY (URNCST) JOURNAL Read more URNCST Journal articles and submit your own today at: https://www.urncst.com

\section{Geology, Physical and Earth Sciences}

A multifaceted approach employing cavitation and multilayered biofilms for groundwater remediation of hydrocarbons

Shalini Bahl, Rasan Sahota

University of Toronto Scarborough, Toronto, Ontario, Canada

Resource extraction process of hydraulic fracturing (HF) has raised concerns due to the addition of toxic hydrocarbon contaminants in groundwater. However, the extent of pollutants introduced by HF in water has been under much dispute. Nonetheless, indication of unsafe levels of harmful toxins warrants to be addressed by a purification system. The current techniques attempt to accomplish this filtration but are inefficient and expensive. Thus, we propose to use a novel purification technique consisting of propeller induced cavitation and multilayered biofilms formed using the microorganisms Dechloromonas aromatica, Marinobacter aquaeolei and Pseudomonas putida - to aid in groundwater remediation of potable water.

Testing alternative hydro fracturing methods against conventional methods Joseph Auger, Ethan Dykstra, Tamjeed Khan, University of Guelph, Guelph, Ontario, Canada

As a key turning point in energy technology of the 21 st century, hydrofracking is one of the greatest discoveries for extracting natural gas from shale deposits. Establishment of hydro fracturing technology gave rise to natural gas industry as the potential leader in energy use and production sector globally. However, there are water use concerns surrounding hydrofracking. The goal of the experiment is to critically analyze the water usage of hydrofracking techniques including conventional, mechanical impulse hydraulic fracking, gas fracking and injection fluid hydraulic fracking. $30 \mathrm{~cm} \mathrm{x} 30 \mathrm{~cm} \mathrm{x}$ $30 \mathrm{~cm}^{3}$ sediment samples consisting of limestone, granite and concrete will undergo experimental fracking using true-triaxial equipment to determine fracking patterns and sediment displacement. The resulted fracking patterns from each treatment will be compared with the cohesive element method to model microstructural damage and initiation of micro cracking at bore hole of the samples. A restricted volume of water will be applied to each treatment to understand the amount of water required to displace fractured sediment. The comparison of the weight before and after the fracking process will determine which technology will be most efficient at fracturing.

\section{Global Health}

Severity of asthma in offspring after gestational exposure to fracking-related air pollution

Rimsha Chattha, Maher Jibrini, Emma Yu

McMaster University, Hamilton, Ontario, Canada

Volatile organic compounds (VOCs) have become a large area of research in regards to their effects on the health of humans; one site of origin of airborne VOCs are fracking sites. Since asthma can be exacerbated by VOCs, this study aims to identify the effects that gestational exposure to fracking-related air pollution has on the severity of asthmatic attacks in the offspring. Asthma is a chronic respiratory disease that leads to a decline in quality of life, making it an essential research focus in the field of health sciences. Using a mouse model of acute asthma, we propose to investigate airway resistance and compliance following gestational exposure to either fracking-related air pollution or filtered air using a FlexiVent system.

The effects of radium-226 in cattle and predicted impacts of cancer

Nayha Eijaz, Bhairavei Gnanamanogaran, Paras Kapoor, Saranya Naraentheraraja

University of Toronto Scarborough, Toronto, Ontario, Canada

Hydraulic fracturing is a controversial method of natural gas extraction that has gained its fair share of critics. Although research has been conducted on the environmental impact of fracking, research concerning naturally occurring radioactive materials (NORM) has been scarce. Radionuclides are known to bioaccumulate in the environment and can have toxic effects on humans. This study aims to examine the extent of biomagnification of radium-226 in soil, crops and animals. Fluid samples from areas near fracking sites will be compared with samples from non-fracking sites via gamma spectroscopy.

Bajwa et al. | URNCST Journal (2018): Volume 2, Issue 3

DOI Link: https://doi.org/10.26685/urncst.47 
UNDERGRADUATE RESEARCH IN NATURAL AND CLINICAL SCIENCE AND TECHNOLOGY (URNCST) JOURNAL Read more URNCST Journal articles and submit your own today at: https://www.urncst.com

Homogenized samples of soil and crops will be analyzed by gamma spectroscopy while milk and cattle meat samples will undergo alpha spectroscopy. This will provide a clear image of the process of bioaccumulation and magnification of radionuclides in the environment as a byproduct of fracking.

\section{An investigation of adsorption of chromium (VI) by Micrococcus spp. encapsulated in a silica gel Louiza Azzouz, Nadiya Bayeva, Jasmine Hartlaub, Zixuan Xiao University of Toronto St.George, Toronto, Ontario, Canada}

Hydraulic Fracturing, or more commonly known as fracking, is a controversial shale oil and gas extraction process. Although the technique is very effective, it often forces many toxic organic and metal pollutants to be forced out of the earth and into the water. Over the years, many water filtration systems have been proposed to clean contaminated groundwater from the oil industry. One promising method includes the use of naturally occurring bacteria to biodegrade or adsorb waste products in water. Bacteria-based water treatment strategies have been shown to be effective and sustainable. The focus of our research proposal is the development a new bioreactor which utilizes silica gel bioencapsulated Micrococcus spp. targeting chromium in fracking groundwater. Silica-based materials have been used for many decades and have recently regained popularity as bioencapsulators. Such a bioreactor will be stable, effective, and environmentally sustainable. This system can be applied to filter drinking water and assure the water quality for communities near fracking sites.

\section{Conflicts of Interest}

The authors have no conflict of interest to declare.

\section{Authors' Contributions}

JG: founder and president of the Undergraduate Research Initiative, served on the planning committee for the USCC, drafted the conference abstract booklet, and gave final approval of the version to be published.

DB: served as design officer and on the planning committee for the USCC, assisted authors with their abstract submissions, and gave final approval of the version to be published.

IC: served as scientific advisor and on the planning committee for the conference, reviewed the abstract submissions and ensured that they adhered to correct formatting standards, and gave final approval of the version to be published.

RR: served as president of Scinapse and chair of the USCC planning committee, assisted authors with their abstract submissions, and gave final approval of the version to be published.

\section{Acknowledgements}

We want to acknowledge the entire Scinapse Provincial Team for playing an integral role in making this year's USCC a big success. The team that helped make this competition possible includes: Rashida Rajgara as President and chair of the planning committee, Jamie Ghossein as President of URI and USCC adviser, Céline Sayed and Dominic Cyr as VicePresident of URI and USCC advisers, Sarah Houssari and Andréa Brabant as communications director, Hannah Evelyn Gorham-Smith, Dilpreet Bajwa, Amanda Vandewint and Bridget Price-Roberts as graphic designers, Iulia Cornila as scientific adviser, Wael Zhaghrini as project coordinator, Rishi Gupta as president of uOttawa USCC chapter, and Dominique Boucher, Nusrah Rajabalee, Sanmeet Chalal and Ahwon Jeong as USCC representatives.

The USCC would not have been successful without the contribution and work of the multiple different chapters of the Scinapse USCC situated across other universities in Ontario. The following are the respective leads of the USCC chapters: Sean Ihn from University of Toronto St. George, Eric Lentz from University of Toronto Scarborough, Kohilan Selvakumaran from McMaster University, Bethany Choi and William He from Western University, Cindy Ha and Tinya Wang from University of Guelph, Vlad Bularca, Austin Jabari, Art Tsai and Ziye Wang from Waterloo University, and Jennifer Manley from Queens University.

We want to acknowledge all the professors and graduate students that participated as judges for the competition. Your valuable time and feedback to the participants has had a positive impact on their future success.

\section{Funding}

The Scinapse USCC is funded by the Undergraduate Research Initiative and contributions from the University of Ottawa Faculty of Science and Faculty of Medicine. 


\section{Article Information}

Managing Editor: Jeremy Y. Ng

Article Dates: Received Mar 18 18; Published Mar 2118

\section{Citation}

Please cite this article as follows:

Bajwa D, Cornila I, Ghossein J, Rajgara R. Scinapse 2017-2018 undergraduate science case competition: What the frack is this? URNCST Journal. 2018 Mar 21: 2(3). https://urncst.com/index.php/urncst/article/view/47

DOI Link: https://doi.org/10.26685/urncst.47

\section{Copyright}

(C) Dilpreet Bajwa, Iulia Cornila, Jamie Ghossein, Rashida Rajgara. (2018). Published first in the Undergraduate Research in Natural and Clinical Science and Technology (URNCST) Journal. This is an open access article distributed under the terms of the Creative Commons Attribution License (https://creativecommons.org/licenses/by/4.0/), which permits unrestricted use, distribution, and reproduction in any medium, provided the original work, first published in the Undergraduate Research in Natural and Clinical Science and Technology (URNCST) Journal, is properly cited. The complete bibliographic information, a link to the original publication on http://www.urncst.com, as well as this copyright and license information must be included.

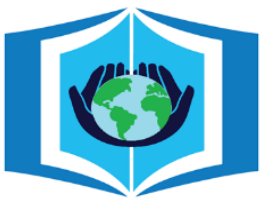

\section{URNCST Journal}

"Research in Earnest"

\section{Funded by the Government of Canada}

\section{Canadà̀}

Do you research in earnest? Submit your next undergraduate research article to the URNCST Journal!

| Open Access | Peer-Reviewed | Rapid Turnaround Time | International |

| Broad and Multidisciplinary | Indexed | Innovative | Social Media Promoted |

Pre-submission inquiries? Send us an email at info@ urncst.com | Facebook, Twitter and LinkedIn: @URNCST

\section{Submit YOUR manuscript today at https://www.urncst.com!}
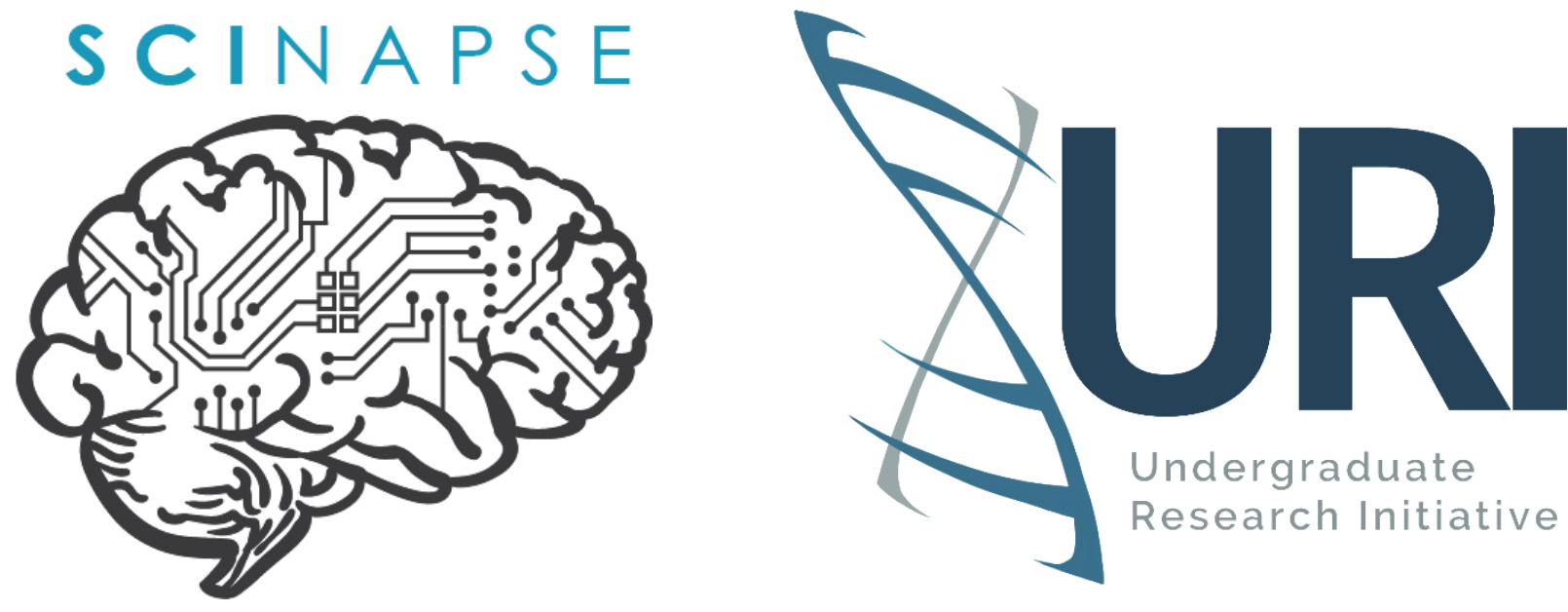